\title{
ANALISIS FAKTOR MOTIVASI, LINGKUGAN KERJA, DISIPLIN DAN PENGARUHNYA TERHADAP KINERJA GURU HONORER DI KABUPATEN TANGERANG
}

\author{
Tri Endi Ardiansyah PS', Abella Sistra P2 \\ Politeknik LP3I Jakarta, FEB Universitas Muhammadiyah Tangerang \\ triendisasongko@gmail.com
}

\begin{tabular}{l|l}
\hline Keyword & Abstract \\
\hline Motivation, work-environtment, & $\begin{array}{l}\text { This research aimed to analys factors motivation, work-environment, } \\
\text { discipline and its impact to work-performance of part-time teacher in } \\
\text { region Tangerang. There are some assumptions in around the } \\
\text { condidition, one of them is compensation package that below than basic } \\
\text { salary standrard. Beside it, there are some assumes tht value and } \\
\text { amount wil equel to quality, performance and spirit to motivate of } \\
\text { teachers. As pre-assumption, motivation of teacher was had to } \\
\text { contribute for assesment of professional performance of teacher and } \\
\text { finally will point to wages and teachers welfare. In this research, } \\
\text { analysis technique by using multi-rergession analysis, hypothesis analysis } \\
\text { by using t-test and f-test. In additional, this research using classical- } \\
\text { assumption test where include normality test, auto-correlation test, } \\
\text { hetereo-schedashticity, multi-coliniearity test. The result of research } \\
\text { shown that motivation, work-environtment and discipline have significant } \\
\text { impact to work-performance of teacher. }\end{array}$
\end{tabular}

(C)2018 JMB, All right reserved

\section{PENDAHULUAN}

\section{Latar Belakang Masalah}

Keberadaan guru honorer pada beberapa waktu terakhir menjadi salah satu perhatian publik. Dimana kualitas profesi, minimnya taraf kesejahteraan guru, motivasi dan faktor lainnya yang pada akhirnya bermuara kepada kualitas hasil didikan. Menurut penelitian yang dilakukan oleh Professor John Hattie dari University of Auckland, faktor dominan penentu prestasi siswa adalah: I) karakteristik siswa (49\%), serta 2) guru (30\%), 3) lain-lain (21\%). Beberapa penelitian lain juga memperlihatkan besarnya pengaruh kemampuan guru terhadap hasil pendidikan. Berdasarkan hasil penelitian tersebut serta pencapaian salah satu sasaran SDG (sustainable development goals), makapeningkatan kualitas guru di Indonesia menjadi upaya strategis yang harus dilakukan yang akan menentukan kualitas generasi berikutnya dari bangsa Indonesia.
Di sisi lain, kemampuan rata-rata calon guru berdasarkan kemampuan menjawab soal uji kompetensi ketika melakukan test calon guru ternyata masih di bawah $50 \%$, yaitu hanya $44 \%$. Kemampuan terendah ada pada kompetensi fisika dan matematika yang hanya mencapai $33 \%$ dan 46\%. Kemampuan tertinggi adalah kompetensi bahasa Inggris yang hanya mencapai $58 \%$. Fakta ini memperlihatkan betapa rendahnya kompetensi para calon guru di Indonesia.

Menurunnya hasil Uji Kompetensi Guru secara signifikan sesudah usia 4I tahun merupakan fakta yang sangat menarik. Tentunya banyak hal yang mungkin jadi faktor penyebabnya. Beberapa hal diantaranya adalah rendahnya motivasi belajar bagi guru setelah usia 40 tahun, sehingga kemampuan nya tidak terupdate lagi, di lain pihak saat ini adalah era dimana ilmu berkembang sangat pesat dan era konvergensi keilmuan, kondusifitas lingkungan Kerja dan tingkat kedisiplan Kerja terumama bagi mereka yang berusia di atas 40 tahun. 


\section{Rumusan Masalah}

Dari latar belakang yang telah dijelaskan diatas peneliti ingin merumuskan masalah yang akan diteliti yaitu Motivasi, Lingkungan Kerja, Disiplin Kerja. Dan apakah Motivasi, Lingkungn Kerja dan Disiplin Kerja secara bersama-sama berpengaruh terhadap Kinerja Guru SD Kabupaten Tangerang ?

\section{TINJAUAN PUSTAKA}

\section{Teori Kebutuhan Maslow}

Abraham Maslow mengemukakan bahwa hierarki kebutuhan manusia adalah sebagai berikut: Kebutuhan fisiologis, yaitu kebutuhan untuk makan, minum, perlindungan fisik bernapas, seksual. Kebutuhan ini disebut pula sebagai kebutuhan yang paling dasar. Kebutuhan rasa aman yaitu kebutuhan akan perlindungan dari ancaman, bahaya, pertentangan, dan lingkungan hidup. Kebutuhan sosial yaitu kebutuhan yang didasarkan oleh sifat lahiriah manusia yang saling berinteraksi satu sama lainnya. Kebutuhan akan harga diri, yaitu kebutuhan untuk dihormati, dan dihargai oleh orang lain.Kebutuhan aktualisasikan diri, yaitu kebutuhan untuk menggunakan kemampuan, skill, dan potensi. Hierarki kebutuhan dari Abraham Maslow ditunjukkan dengan bentuk piramida pada Gambar 2.I.

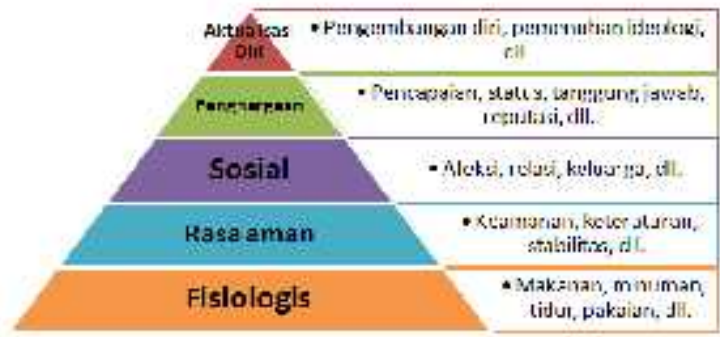

\section{Gambar I.Hierarki Kebutuhan Dari Abraham Maslow}

\section{Teori Motivasi}

Motivasi tidak dapat diamati secara langsung tetapi dapat diinterprestasikan dari tingkah lakunya. (Septiana, 2013). Motivasi dalam kajian keilmuan, lebih menitik beratkan pada bagaimana caranya mengarahkan daya dan potensi bawahan, agar mau bekerja sama secara produktif berhasil mencapai dan mewujudkan tujuan yang telah ditentukan. Dorongan atau tenaga tersebut merupakan gerak jiwa dan jasmani untuk berbuat akan sesuatu, sehingga motif tersebut merupakan driving force yang menggerakkan manusia untuk bertingkah laku dan di dalam perbuatannya itu mempunyai tujuan tertentu. Seperti dorongan dalam diri seseorang untuk melakukan kegiatan-kegiatan agar tercapai suatu tujuan. (Hamali, 20 I8:134).

Adapun faktor-faktor yang dapat mendorong seseorang untuk melakukan pekerjaannya secara lebih bersemangat sehingga memperoleh prestasi yang lebih baik. Faktorfaktor tersebut antara lain faktor intrinsik yaitu faktor-faktor yang timbul dari dirinya sendiri yaitu keinginan untuk berprestasi, keinginan untuk maju, pemberian tanggung jawab (responsibility). Faktor ekstrinsik, yaitu faktor dari luar, disini seorang guru yang akan mempengaruhi semangatnya dalam bekerja, dimana indikatornya adalah Pekerjaan itu sendiri atau pekerjaan guru tersebut, Lingkungan kerja Keamanan, Gaji atau penghasilan, Pengakuan dan penghargaan, Kepercayaan, Kebijakan pimpinan.

\section{Teori Lingkungan Kerja}

Menurut Sedarmayanti lingkungan kerja terbagi menjadi 2 kategori, yaitu: Lingkungan kerja fisik dan lingkungan Kerja perantara. Lingkungan kerja fisik adalah semua keadaan yang terdapat di sekitar tempat kerja, akan mempengaruhi pegawai baik secara langsung maupun tidak langsung. Lingkungan kerja perantara dapat juga disebut lingkungan kerja yang mempengaruhi kondisi manusia, misalnya: temperatur, kelembaban, sirkulasi udara, pencahayaan dan lain-lain.

Suatu kondisi lingkungan dikatakan baik atau sesuai apabila manusia dapat melaksanakan kegiatannya secara optimal, sehat, aman dan nyaman sehingga dapat meningkatkan gairah kerja para karyawan. Berikut adalah beberapa indikator yang dijelaskan oleh Sedarmayanti (201 I:28-35) yaitu: Penerangan/cahaya di tempat kerja, Temperature/suhu udara di tempat kerja, Kelembaban di tempat kerja, Sirkulasi udara di tempat kerja, Kebisingan di tempat kerja, Keamanan di tempat kerja.

\section{Disiplin Kerja}


Disiplin dapat diartikan sebagai sikap hormat terhadap peraturan dan ketetapan perusahaan, yang ada dalam diri karyawan, yang menyebabkan karyawan dapat menyesuaikan diri dengan sukarela pada peraturan dan ketetapan perusahaan (Hamali, 2018:2/4). Menurut Hasibuan, 2017 pada dasarnya banyak indikator yang mempengaruhi tingkat kedisiplinan pegawai diantaranya : (a) Tujuan dan Kemampuan, tujuan yang dicapai harus jelas dan ditetapkan secara ideal serta cukup menantang bagi kemampuan pegawai. (b) Balas Jasa, jika kecintaan pegawai semakin baik terhadap pekerjaan, kedisiplinan mereka akan semakin baik pula. (c)Keadilan, keadilan yang dijadikan dasar kebijakan dalam pemberian balas jasa (pengakuan) atau hukuman akan merangsang terciptanya kedisiplinan pegawai yang baik. (d)Sanksi Hukum, dengan sanksi hukuman yang berimbang maka pegawai akan semakin takut melanggar peraturanperaturan, sikap dan perilaku indisipliner pegawai akan berkurang. (e) Ketegasan, ketegasan pimpinan menegur dan menghukum setiap pegawai yang indisipliner akan mewujudkan kedisiplinan yang baik pada suatu instansi. (Hasibuan, 2017:195-198).

\section{Teori Kinerja}

Moeheriono berpendapat, kinerja atau "performance" adalah hasil kerja yang dapat dicapai oleh seseorang atau sekelompok orang dalam suatu organisasi, baik secara kuantitatif maupun kualitatif, sesuai dengan kewenangan dan tugas tanggung jawab masing-masing dalam upaya mencapai tujuan organisasi bersangkutan secara legal, tidak melanggar hukum dan sesuai dengan moral maupun etika (Abas, 20l7:23). Pendapat yang hampir senada diungkapkan oleh McDaniel sebagaimana dikutip Uno yang mengemukakan kinerja adalah interaksi antara kemampuan seseorang dengan motivasinya. (Abas, 2017:23-24). Pendapat lain menyatakan bahwa kinerja guru merupakan suatu perilaku atau respons yang memberikan hasil yang mengacu kepada apa yang mereka kerjakan ketika menghadapi tugas. (Abas, 2017:24).

Sementara Kementrian Pendidikan dan Kebudayaan RI mengemukakan tujuh unsur yang merupakan indikator prestasi kerja guru atau kinerja guru, yaitu (Abas, 2017:26) : Penguasaan Landasan Kependidikan, Penguasaan bahan pengajaran, Pengelolaan program belajar mengajar, Penggunaan alat pelajaran. Dengan demikian kinerja guru pada dasarnya lebih terarah pada perilaku seorang pendidik dalam pekerjaanya dan efektivitas pendidik dalam menjalankan tugas dan tanggung jawabnya yang dapat memberikan pengaruh kepada peserta didik kepada tujuan yang diingikannya. (Abas, 2017:24).

\section{Pengembangan Hipotesis Penelitian}

Motivasi terhadap kinerja guru dapat di simpulkan bahwa motivasi guru berpengaruh secara positif terhadap kinerja guru, apabila tingkat motivasi guru mengalami kenaikan maka kinerja guru SD di Kabupaten Tangerang juga mengalami kenaikan, begitu pula sebaliknya apabila motivasi guru menurun maka kinerja guru SD di Kabupaten Tangerang menurun. Berdasarkan uraian diatas maka hipotesis penelitian ini adalah:

$\mathbf{H}_{\mathbf{I}}$ : Motivasi berpengaruh positif terhadap Kinerja Guru

Kondisi lingkungan kerja dikatakan baik apabila pegawai dapat melaksanakan kegiatan secara optimal, sehat, aman, dan nyaman, sebab itu akan berpengaruh langsung terhadap kinerja karyawan dalam meningkatkan kinerja.

$\mathbf{H}_{\mathbf{2}}$ : Lingkungan Kerja berpengaruh positif terhadap Kinerja Guru

Disiplin di lingkungan kerja sangat dibutuhkan, karena akan berdampak kepada pencapaian tujuan organisasi. Dimana didalamnya terdapat unsure peraturan yang jelas, mudah dimengerti, berkeadilan bagi seluruh pemangku kepentingan. Disiplin Kerja berpengaruh secara parsial terhadap Kinerja Guru.

$\mathbf{H}_{3}$ : Disiplin Kerja berpengaruh positif terhadap Kinerja Guru

Wujud kinerja dapat dilihat dari tingkat prestasi kerja yang berupa hasil kerja, kemampuan dan penerimaan atas kejelasan delegasi tugas serta minat seorang pekerja.hal ini dapat diihat denga mengelaborasikan factor motivasi, lingkungan dan disiplin kerja.

$\mathbf{H}_{4}$ : Motivasi, Lingkungan Kerja dan Disiplin Kerja berpengaruh positif terhadap Kinerja Guru.

\section{IIIMETODOLOGI PENELITIAN}

\section{Desain Penelitian}

Metodologi penelitian adalah cara ilmiah untuk mendapatkan data objektif, valid dan variabel dengan tujuan untuk menentukan, membuktikan dan mengembangkan suatu pengetahuan, sehingga digunakan untuk memecahkan dan mengidentifikasi masalah yang ada. Dalam penelitian ini penulis menggunakan metodologi penelitian kuantitatif yang 
merupakan data bentuk angka atau data kuantitatif.

\section{Populasi dan Sampel}

Populasi yang digunakan dalam penelitian ini adalah guru-guru yang ada di Kabupaten Tangerang pada tahun 2018. Jumlah populasi sebanyak 12.622 guru. Sampel penelitian sekolah ini diambil secara Purposive
Sampling. Metode Purposive Sampling merupakan metode pengambilan sampel yang didasarkan pada beberapa pertimbangan atau kriteria tertentu. Dimana sampel digunakan apabila memenuhi kriteria-kriteria sebagai berikut : SD Negeri yang sudah terakreditasi, Fasilitas di sekolah lengkap, Luas tanah yang dimiliki $\geq$ I.500 M².

Tabel I.Kriteria Pemilihan Sampel

\begin{tabular}{|l|c|}
\hline Total Sekolah & 974 \\
\hline Sekolah yang berstatus swasta & $(218)$ \\
\hline Sekolah yang belum Terakreditasi & $(491)$ \\
\hline Sekolah dengan fasilitas tidak lengkap & $(157)$ \\
\hline Sekolah dengan luas tanah < I500 M² & $(105)$ \\
\hline Total Sekolah yang terpilih menjadi sampel & 3 \\
\hline Sumber: Hasil data diolah, 2018
\end{tabular}

Yang menjadi responden dalam penelitian ini adalah guru dari 3 sekolah yang sudah terpilih, yaitu 64 guru dengan menggunakan sampel jenuh dari total keseluruhan guru di 3 sekolah tersebut.

\section{Definisi Operasional Variabel}

Menurut Sugiyono (2017:38), variabel penelitian pada dasarnya adalah segala sesuatu yang berbentuk apa saja yang ditetapkan peneliti untuk dipelajari sehingga diperoleh informasi tentang hal tersebut kemudian ditarik kesimpulannya. Variabel-variabel yang digunakan dalam penelitian adalah :
I. Variabel Bebas (Independen Variable) Yang menjadi varibel independen penelitian ini adalah:

Variabel bebas $\left(X_{1}\right)$ pada penelitian ini adalah Motivasi, sedangkan variabel $\left(X_{2}\right)$ Lingkungan Kerja dan variabel $\left(X_{3}\right)$ Disiplin Kerja.

2. Variabel Terikat (Dependent Variable)

Variabel terikat (Y) pada penelitian ini adalah Kinerja Guru. Kinerja adalah pencapaian prestasi seseorang berkenaan dengan tugas-tugas yang dibebankan kepadanya.

Tabel 2. Operasional Variabel Motivasi

\begin{tabular}{|c|cl|c|c|}
\hline Variabel & \multicolumn{2}{|c|}{ Indikator } & Skala & Item Pertanyaan \\
\hline \multirow{2}{*}{$\begin{array}{c}\text { Motivasi } \\
(\mathbf{X I})\end{array}$} & I. & Kompensasi & Ordinal & $1,2,3,4$ \\
\cline { 2 - 5 } & 2. & Lingkungan & Ordinal & $5,6,7$ \\
\cline { 2 - 5 } & 3. & Promosi & Ordinal & $8,9,10$ \\
\hline
\end{tabular}

Sumber : Hasil data diolah, 2018

Tabel 3. Operasional Variabel Lingkungan Kerja

\begin{tabular}{|c|l|l|c|}
\hline Variabel & \multicolumn{1}{|c|}{ Indikator } & Skala & Item Pertanyaan \\
\hline \multirow{4}{*}{$\begin{array}{c}\text { Lingkungan } \\
\text { Kerja } \\
(\mathbf{X})\end{array}$} & I. Penerangan & Ordinal & $\mathrm{I}, 2$ \\
\cline { 2 - 4 } & 2. Temperature udara & Ordinal & 3,4 \\
\cline { 2 - 4 } & 3. Kelembaban & Ordinal & 5,6 \\
\cline { 2 - 4 } & 4. Sirkulasi udara & Ordinal & 7,8 \\
\cline { 2 - 4 } & 5. Kebisingan & Ordinal & 9,10 \\
\cline { 2 - 4 } & 6. Keamanan & Ordinal & $\mathrm{II}, 12$ \\
\hline
\end{tabular}


Tabel 4. Operasional Variabel Disiplin Kerja

\begin{tabular}{|c|c|c|c|}
\hline Variabel & Indikator & Skala & Item Pertanyaan \\
\hline \multirow{6}{*}{$\begin{array}{c}\text { Disiplin } \\
\text { Kerja (X3) }\end{array}$} & I. Tujuan \& Kemampuan & Ordinal & 1,2 \\
\hline & 2. Teladan Pimpinan & Ordinal & 3,4 \\
\hline & 3. Balas Jasa & Ordinal & 5,6 \\
\hline & 4. Keadilan & Ordinal & 7,8 \\
\hline & 5. Sanksi Hukum & Ordinal & 9,10 \\
\hline & 6. Ketegasan & Ordinal & 11,12 \\
\hline
\end{tabular}

Sumber : Hasil data diolah, 2018

Tabel 5. Operasional Variabel Kinerja Guru

\begin{tabular}{|c|l|c|c|}
\hline Variabel & \multicolumn{1}{|c|}{ Indikator } & Skala & Item Pertanyaan \\
\hline \multirow{4}{*}{$\begin{array}{c}\text { Kinerja } \\
\text { Guru } \\
\text { (Y) }\end{array}$} & $\begin{array}{l}\text { I. Penguasaan Landasan } \\
\text { Pendidikan }\end{array}$ & Ordinal & $\mathrm{I}, 2,3$ \\
\cline { 2 - 4 } & 2. Penguasaan Bahan Ajar & Ordinal & 4,5 \\
\cline { 2 - 4 } & $\begin{array}{l}\text { 3. Pengelolaan Program } \\
\text { Belajar Mengajar }\end{array}$ & Ordinal & $6,7,8$ \\
\cline { 2 - 4 } & 4. Penggunaan Alat Pelajaran. & Ordinal & 9,10 \\
\hline
\end{tabular}

Sumber : Hasil data diolah, 2018

Operasionalisasi variabel juga digunakan sebagai dasar pembuatan kuesioner, sehingga dapat membantu dalam mendapatkan data setepat mungkin. Dalam penelitian ini, kuisioner menggunakan pertanyaan tertutup yang akan membantu responden untuk menjawab dengan cepat, dan juga memudahkan peneliti dalam melakukan analisis data terhadap seluruh kuisioner yang telah terkumpul. Pertanyaan tertutup menggunakan skala likert.

Tabel 6. Skala Likret

\begin{tabular}{|c|c|}
\hline Variabel adalah menyangkut & Skor \\
\hline Sangat Setuju (SS) & 5 \\
\hline Setuju (S) & 4 \\
\hline Ragu-Ragu (RR) & 3 \\
\hline Tidak Setuju (TS) & 2 \\
\hline Sangat Tidak Setuju (STS) & I \\
\hline Sumber : Hasil data diolah, 2018
\end{tabular}

\section{Metode Pengumpulan Data}

Pendekatan penelitian yang digunakan dalam penelitian ini adalah dengan menggunakan analisis deskriptif dengan pendekatan kuantitatif. Data yang disunakan dalam penelitian ini adalah data primer dan data sekunder. Sumber data primer merupakan sumber data yang didapat dan diolah secara langsung dari subjek yang berhubungan langsung dengan penelitian diantaranya di dapat dari data hasil observasi langsung dan data pengisian kuesioner oleh guru SD (Sekolah Dasar) se-Kabupaten Tangerang. Adapun data-data tersebut didapat dengan cara menggunakan kuisioner dan wawancara. Data sekunder adalah sebagai penunjang yang menguatkan perolehan data hasil yang didapat dari observasi melalui artikel, internet, dan dokumen-dokumen yang dimiliki organisasi yang berkaitan dengan kegiatan penelitian.

\section{Teknik Analisis Data}

Teknik analisis data yang digunakan adalah analisis deskriptif dimana statistik yang digunakan untuk menganalisa data dengan cara mendeskripsikan atau menggambarkan data yang ditujukan untuk memberikan gambaran mengenai karakteristik data berupa kecenderungan respon subyek penelitian (berupa mean rata-rata) terhadap variabelvariabel penelitian. Adapun uji data dengan menggunakan uji validitas dan uji realibiitas. Dimana uji validitas degan pendekatan instrumen yang digunakan untuk mendapatkan data (mengukur) data valid. Disamping itu instrumen ini untuk menyatakan item yang mempunyai korelasi positif dengan kriterium (skor total) serta korelasi yang tinggi pula menunjukan bahwa item tersebut mempunyai validitas yang tinggi pula. 


$$
r=\frac{N \cdot\left(\sum x\right)-\left(\sum x\right) \cdot\left(\sum y\right)}{\sqrt{N} \cdot \sum x^{2}-\left(\sum x\right)^{2} \cdot \sqrt{N} \cdot \sum y^{2}-\left(\sum y\right)^{2}}
$$

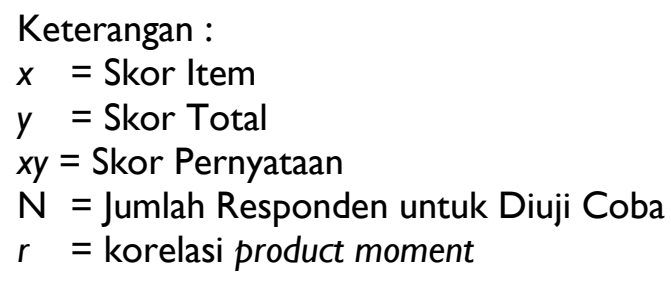

Untuk mengetahui skor masing-masing item pertanyaan valid atau tidak, maka ditetapkan kriteria statistik sebagai berikut:

1) Jika $r$ hitung $>r$ tabel dan bernilai positif, maka variabel tersebut valid.

2) Jika $r$ hitung $<r$ tabel dan bernilai negative, maka variabel tersebut tidak valid.

Sedangkan uji realibiitas instrument yang bila digunakan beberapa kali untuk mengukur objek yang sama, akan menghasilkan data yang sama. Untuk mengetahui suatu alat ukur itu reliabel dapat diuji dengan menggunakan rumus Spearman Brown sebagai berikut:

$$
r 1=\frac{2 r_{i}}{1+r_{i}}
$$

Keterangan :

$r_{i}=$ Reliabilitas internal seluruh instrument

$r_{b}=$ Korelasi product moment antara belahan pertamadan kedua.

Setelah dapat nilai reliabilitas instrument $\left(r_{\text {hitung }}\right)$, maka nilai tersebut dibandingkan dengan $r$ tabel jumlah responden dengan taraf nyata.Bila $r$ hitung $>$ dari $r$ tabel, maka instrument tersebut dikatakan reliabel, sebaliknya jika $r$ hitung $<r$ tabel, maka instrument tersebut dikatakan tidak reliabel. Selain uji vaiditas dan realibilitas, dilakukan juga dengan uji asumsi klasik yang terdiri dari uji normalitas bertujuan untuk menguji apakah dalam model regresi, $U_{j i}$ multikolonieritas bertujuan untuk menguji apakah model regresi ditemukan adanya korelasi antar variabel bebas (independen), uji heteroskedastisitas bertujuan menguji apakah dalam model regresi terjadi ketidaksamaan variance dari residual satu pengamatan ke pengamatan yang lain.

\section{HASIL ANALISIS DAN PEMBAHASAN}

\section{Analisi Data}

\section{Analisis Statistik Deskriptif}

Untuk memberikan gambaran atau deskriptif terhadap variabel-variabel yang digunakan dalam penelitian ini. Variabel yang digunakan meliputi Kinerja Guru, Motivasi, Lingkungan Kerja dan Disiplin Kerja. Dari hasil pengujian statistik deskriptif atas keempat variabel tersebut melalui data asli, maka diperoleh hasil sesuai dengan tabel di bawah ini :

Tabel 7. Descriptive Statistics

\begin{tabular}{|l|r|r|r|r|r|}
\hline & $\mathrm{N}$ & Minimum & Maximum & \multicolumn{1}{|c|}{ Mean } & Std. Deviation \\
\hline KinerjaGuru & 64 & 3 & 4 & 3,65 &, 166 \\
Motivasi & 64 & 3 & 4 & 3,69 &, 134 \\
LingkunganKerja & 64 & 4 & 4 & 3,85 &, 134 \\
DisiplinKerja & 64 & 4 & 4 & 3,88 &, 132 \\
Valid N (listwise) & 64 & & & \\
\hline Sumber : Hasil SPSS (data diolah 2018)
\end{tabular}

Pada tabel 7 terlihat bahwa nilai minimum Kinerja Guru adalah 3 maksimum adalah 4. Nilai rata-rata variabel Kinerja Guru sebesar 3,65 dengan standar deviasi 0,I66.Motivasi merupakan salah satu variabel untuk mengetahui seberapa besar kinerja guru dalam melaksanakan tanggung jawabnya. Rata-rata motivasi selama tahun
2018 diperoleh sebesar 3,69 dengan nilai standar deviasi sebesar 0,134. Lingkungan kerja merupakan salah satu faktor yang dapat mendorong kinerja guru, lingkungan yang baik akan membawa dampak yang baik pula pada kinerja guru tersebut. Rata-rata nilai lingkungan kerja selama tahun 2018 diperoleh sebesar 3,85 dengan nilai standar 
deviasi sebesar 0,134.Disiplin kerja merupakan variabel yang dapat meningkatkan kinerja seorang guru, kinerja guru dapat dikatakan baik apabila guru tersebut mampu mentaati peraturan yang sudah ditentukan. Rata-rata nilai disiplin kerja sebesar 3,88 dengan nilai standar deviasi sebesar 0,132 .

\section{Uji Validitas \& Reliabilitas Uji Validitas}

Pada penelitian ini jumlah sampel $(n)=64$ dan besarnya $d f$ dapat dihitung $64-3=6 \mathrm{I}$, dengan $d f=6 \mathrm{I}$ dan alpha $=0,05$ didapat $r$ tabel dengan uji dua sisi $=0,248$. Jika $r$ hitung lebih besar dari $r$ tabel dan bernilai positif, maka butir pertanyaan atau indikator tersebut dinyatakan valid. Hasil uji validitas pada indikator-indikator penelitian ini terdapat pada tabel berikut:

Tabel 8. Hasil Uji Validitas Variabel Motivasi

\begin{tabular}{|c|c|c|c|}
\hline Variabel & r Hitung & r Tabel & Kriteria \\
\hline X101 & 0,503 & 0,248 & Valid \\
\hline X102 & 0,640 & 0,248 & Valid \\
\hline X103 & 0,708 & 0,248 & Valid \\
\hline$\times 104$ & 0,573 & 0,248 & Valid \\
\hline$\times 105$ & 0,459 & 0,248 & Valid \\
\hline$\times 106$ & 0,555 & 0,248 & Valid \\
\hline X107 & 0,704 & 0,248 & Valid \\
\hline X108 & 0,640 & 0,248 & Valid \\
\hline X109 & 0,708 & 0,248 & Valid \\
\hline X110 & 0,706 & 0,248 & Valid \\
\hline
\end{tabular}

Sumber : Hasil SPSS (data diolah 2018)

Tabel 9. Hasil Uji Validitas Variabel Lingkungan Kerja

\begin{tabular}{|c|c|c|c|}
\hline Variabel & $\mathbf{r}$ Hitung & $\mathbf{r}$ Tabel & Kriteria \\
\hline X20I & 0,612 & 0,248 & Valid \\
\hline X202 & 0,595 & 0,248 & Valid \\
\hline X203 & 0,727 & 0,248 & Valid \\
\hline X204 & 0,566 & 0,248 & Valid \\
\hline X205 & 0,488 & 0,248 & Valid \\
\hline X206 & 0,578 & 0,248 & Valid \\
\hline X207 & $0,65 I$ & 0,248 & Valid \\
\hline X208 & 0,460 & 0,248 & Valid \\
\hline X209 & 0,507 & 0,248 & Valid \\
\hline X210 & 0,576 & 0,248 & Valid \\
\hline X21I & 0,462 & 0,248 & Valid \\
\hline X212 & 0,727 & 0,248 & Valid \\
\hline Sumber : Hasil SPSS (data diolah 20I8)
\end{tabular}

Tabel I0. Hasil Uji Validitas Variabel Disiplin Kerja

\begin{tabular}{|c|c|c|c|}
\hline Variabel & r Hitung & r Tabel & Kriteria \\
\hline X301 & 0,572 & 0,248 & Valid \\
\hline X302 & 0,571 & 0,248 & Valid \\
\hline X303 & 0,706 & 0,248 & Valid \\
\hline X304 & 0,607 & 0,248 & Valid \\
\hline X305 & 0,607 & 0,248 & Valid \\
\hline X306 & 0,468 & 0,248 & Valid \\
\hline X307 & 0,681 & 0,248 & Valid \\
\hline X308 & 0,347 & 0,248 & Valid \\
\hline X309 & 0,706 & 0,248 & Valid \\
\hline X310 & 0,574 & 0,248 & Valid \\
\hline X311 & 0,573 & 0,248 & Valid \\
\hline X312 & 0,706 & 0,248 & Valid \\
\hline
\end{tabular}

Sumber : HasilSPSS (data diolah 2018) 
Tabel I I. Hasil Uji Validitas Variabel Kinerja Guru

\begin{tabular}{|c|c|c|c|}
\hline Variabel & r Hitung & r Tabel & Kriteria \\
\hline Y0I & $0,48 I$ & 0,248 & Valid \\
\hline Y02 & 0,656 & 0,248 & Valid \\
\hline Y03 & 0,793 & 0,248 & Valid \\
\hline Y04 & 0,520 & 0,248 & Valid \\
\hline Y05 & $0,45 I$ & 0,248 & Valid \\
\hline Y06 & 0,793 & 0,248 & Valid \\
\hline Y07 & $0,59 I$ & 0,248 & Valid \\
\hline Y08 & 0,724 & 0,248 & Valid \\
\hline Y09 & 0,656 & 0,248 & Valid \\
\hline Y10 & 0,793 & 0,248 & Valid \\
\hline Sumber : Hasil SPSS (data diolah 2018)
\end{tabular}

Berdasarkan pengujian pada tabel uji validitas diatas, diketahui bahwa nilai $r$ hitung dari semua indikator variabel lebih besar dari $r$ tabelnya. Oleh karena itu dapat disimpulkan bahwa semua indikator dalam penelitian ini adalah valid.

\section{Uji Reliabilitas}

Suatu variabel dikatakan reliabil jika memberikan nilai Cronbach Alpha> 0,6. Adapun hasil uji reliabil dalam penelitian ini dapat dilihat dalam tabel 12 berikut ini.

Tabel I 2. Hasil Uji Reliabelitas

\begin{tabular}{|l|c|l|}
\hline \multicolumn{1}{|c|}{ Variabel } & Cronbach Alpha & Status \\
\hline Motivasi $(\mathrm{XI})$ & 0,884 & Reliabel \\
\hline Lingkungan Kerja (X2) & 0,880 & Reliabel \\
\hline Disiplin Kerja (X3) & 0,888 & Reliabel \\
\hline Kinerja Guru (Y) & 0,897 & Reliabel \\
\hline \multicolumn{2}{|l}{} \\
\hline \multicolumn{2}{l}{} \\
\hline
\end{tabular}

Berdasarkan pengujian pada Tabel 12 Uji Reliabilitas diketahui bahwa semua variabel mempunyai Cronbach Alpha lebih besar dari 0,06 artinya keseluruhan variabel dalam penelitian ini adalah Reliabel.
Uji asumsi klasik dilakukan untuk memastikan bahwa sampel yang diteliti memiliki data yang terdistribusi dengan normal, dan terbebas dari ganguan multikolinieritas, autokorelasi, dan heteroskedastisitas.

a. Uji Normalitas

\section{Uji Asumsi Klasik}


Pengujian ini dilakukan dengan menggunakan uji Kolmogorov-Smirnov. Hasil

pengujian ini dapat dilakukan dengan melihat tabel 13 berikut:

Tabel 13. Hasil Uji Normalitas

One-Sample Kolmogorov-Smirnov Test

\begin{tabular}{|ll|r|}
\hline & & KinerjaGuru \\
\hline Normal Parameters ${ }^{\mathrm{a}, \mathrm{b}}$ & Mean & 64 \\
& Std. Deviation & 3,65 \\
Most Extreme Differences & Absolute &, 166 \\
& Positive &, 080 \\
& Negative &, 080 \\
Test Statistic & &,- 079 \\
Asymp. Sig. (2-tailed) & &, 080 \\
\hline
\end{tabular}

Sumber : Hasil SPSS (data diolah 2018)

Berdasarkan nilai tabel diatas nilai Asymp. Sig 0,200, hal ini mempunyai arti bahwa data yang digunakan oleh peneliti telah berdistribusi normal dikarenakan nilai signifikansinya lebih dari 0,05 yaitu $0,200 \quad(0,200>0,05)$. Penentuan suatu variabel terdistribusi normal atau tidak juga dapat dilihat melalui grafik normal probability plot yang penyebaran titik-titik variabelnya seharusnya berada tidak jauh disekitar garis $Y=X$ dan histogram yang membentuk kurva normal (normal curve). Adapun grafik plot penelitian ini terlihat pada gambar 2 dibawah ini :

\section{Gambar 2. GrafikNormal P-Plot}

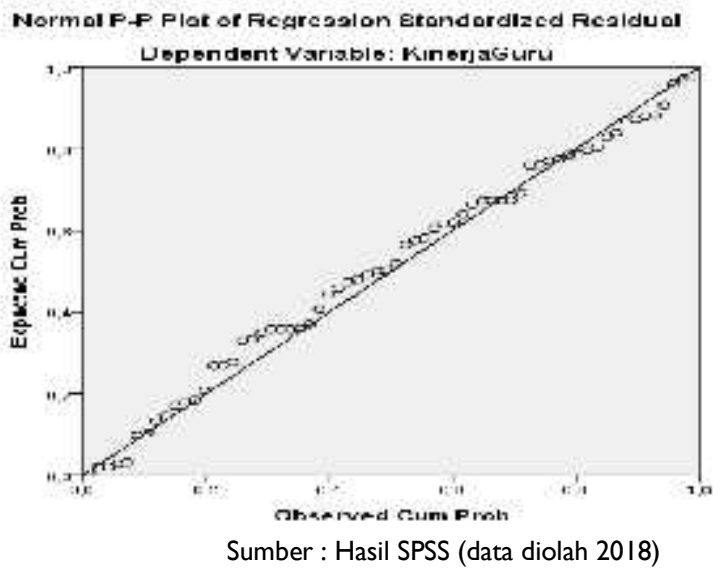

Dari tampilan grafik diatas, maka dapat disimpulkan bahwa model regresi dalam penelitian ini memenuhi asumsi normalitas atau dengan kata lain menunjukkan bahwa data terdistribusi secara normal.

\section{b. Uji Multikolonieritas}

Uji ini dilakukan dengan Tolerance Value dan Variance Inflation Factor (VIF). Agar tidak terjadi multikolinearitas, batas Tolerance Value $>0, I$ dan VIF $<10$. Adapun hasil uji multikolinearitas pada penelitian ini dapat dilihat pada tabel 14 di bawah ini :

Tabel I4. Hasil Uji Multikolonieritas

\begin{tabular}{|c|c|c|}
\hline \multirow[b]{2}{*}{ Model } & \multicolumn{2}{|c|}{ Collinearity Statistics } \\
\hline & Tolerance & VIF \\
\hline (Constant) & & \\
\hline Motivasi & , 165 & 6,049 \\
\hline LingkunganKerja & 228 & 4,387 \\
\hline DisiplinKerja & 473 & 9,451 \\
\hline
\end{tabular}


Hasil perhitungan nilai

Variance Inflation Factor (VIF) menunjukkan semua variabel independen yaitu motivasi, lingkungan kerja dan disiplin kerja memiliki nilai VIF kurang dari 10. Dan hasil nilai perhitungan nilai tolerance pada setiap variabel mempunyai nilai lebih dari 0,I0. Artinya, bahwa variabel bebas dalam penelitian ini tidak saling berkorelasi atau tidak ditemukan adanya korelasi antar variabel bebas yang ditunjukkan dengan nilai tolerance $\geq 0, I$ dan nilai VIF $\leq$

10.

Sumber : Hasil SPSS (data diolah 2018)

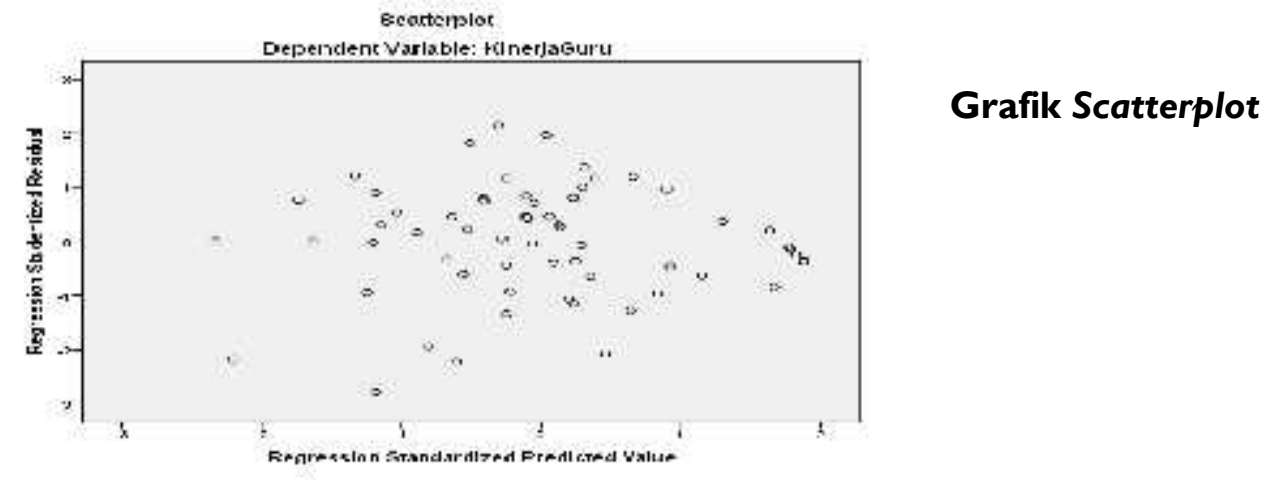

c. Uji Heteroskedastisitas

Pada penelitian ini uji heteroskedastisitas yang digunakan adalah melalui grafik plot antara nilai prediksi variabel terikat (ZPRED) dengan residualnya (SRESID). Adapun grafik hasil pengujian heteroskedastisitas menggunakan SPSS dapat dilihat pada gambar 3 dibawah ini :

\section{Gambar 3.}

Dari grafik scatterplot diatas terlihat bahwa titik-titik menyebar secara acak serta tersebar baik di atas maupun di bawah angka 0 (nol) pada sumbu Y. Maka dapat disimpulkan bahwa tidak terdapat gejala heteroskedastisitas pada model regresi yang digunakan.

\section{Uji Hipotesis}

\section{Uji Parsial (Uji t)}

Pengujian terhadap hasil regresi dilakukan dengan menggunakan uji $t$ pada derajat keyakinan sebesar $95 \%$ atau $\alpha=5 \%$. Berikut penjelasan yang diperoleh dari hasil uji t statistik :

Tabel I5. Hasil Uji t

\begin{tabular}{|c|c|c|c|c|c|c|}
\hline \multirow{2}{*}{\multicolumn{2}{|c|}{ Model }} & \multicolumn{2}{|c|}{ Unstandardized Coefficients } & \multirow{2}{*}{$\begin{array}{c}\begin{array}{c}\text { Standardized } \\
\text { Coefficients }\end{array} \\
\text { Beta }\end{array}$} & \multirow[b]{2}{*}{$\mathrm{t}$} & \multirow[b]{2}{*}{ Sig. } \\
\hline & & $B$ & Std. Error & & & \\
\hline \multirow[t]{4}{*}{$\mathrm{I}$} & (Constant) & 6,822 & 2,071 & & 3,294 &, 002 \\
\hline & Motivasi &, 414 & , 145 & ,357 & 2,848 &, 006 \\
\hline & Lingkungan & ,704 & , 107 & ,716 & 6,603 &, 000 \\
\hline & Disiplin & $\mathrm{I}, 034$ & ,221 & 1,025 & 4,669 &, 000 \\
\hline
\end{tabular}

Berdasarkan hasil olahan data pada tabel diatas, maka dapat dilihat Motivasi memiliki nilai signifikansi sebesar 0,006. Nilai signifikansi lebih kecil dari $0,05(0,006<0,05)$, maka $\mathrm{H}_{0}$ ditolak dan $\mathrm{H}_{\text {। }}$ diterima. Variabel
$X_{1}$ mempunyai $t_{\text {hitung }}=2,848$ dengan $\mathrm{t}_{\text {tabel }}=2,00030$. Jadi $\mathrm{t}_{\text {hitung }}>\mathrm{t}_{\text {tabel }}=$ 2,848>2,00030. Jadi dapat disimpulkan bahwa Motivasi berpengaruh positif signifikan terhadap Kinerja Guru. 
Lingkungan Kerja memiliki nilai signifikansi sebesar 0,000 . Maka $\mathrm{H}_{0}$ ditolak dan $\mathrm{H}_{2}$ diterima. Variabel $\mathrm{X}_{2}$ mempunyai $t_{\text {hitung }}=6,603$ dengan $t_{\text {tabel }}=2,00030$. Jadi $t_{\text {hitung }}>t_{\text {tabel }}=$ $6,603>2,00030$. Jadi dapat disimpulkan bahwa Lingkungan Kerja berpengaruh positif dan signifikan terhadap Kinerja Guru. Disiplin Kerja memiliki nilai signifikan sebesar 0,000 . Nilai signifikansi lebih kecil dari 0,05 maka $\mathrm{H}_{0}$ diterima dan $\mathrm{H}_{3}$ ditolak. Variabel $X_{3}$ mempunyai thitung 4,669 dengan $t_{\text {tabel }} 2,00030$. Jadi $t_{\text {hitung }}>t_{\text {tabel }}$ $=4,669>2,00030$. Jadi dapat disimpulkan bahwa Disiplin Kerja berpengaruh positif signifikan terhadap Kinerja Guru.

\section{Uji Simultan F (Uji F)}

Tingkat signifikan yang digunakan dalam penelitian ini yaitu nilai $\alpha=$ $5 \%$.

jika nilai $F_{\text {hitung }}>F_{\text {tabel, }}$ maka $H_{1}$ diterima dan $\mathrm{H}_{0}$ ditolak

jika nilai $F_{\text {hitung }}<F_{\text {tabel, }}$ maka $\mathrm{H}_{0}$ diterima dan $\mathrm{H}_{\text {, ditolak. }}$

Hasil uji statistik $\mathrm{F}$ dalam penelitian ini ditampilkan pada tabel dibawah ini :

Tabel I6. Hasil Uji F

\begin{tabular}{|c|c|c|c|c|c|c|}
\hline \multicolumn{2}{|c|}{ Model } & Sum of Squares & Df & Mean Square & $F$ & Sig. \\
\hline \multirow[t]{3}{*}{1} & Regression & 2230,512 & 3 & 743,504 & 173,252 &, $000^{b}$ \\
\hline & Residual & 257,488 & 60 & 4,291 & & \\
\hline & Total & 2488,000 & 63 & & & \\
\hline
\end{tabular}

Sumber : Hasil SPSS (data diolah 20I8)

Tabel di atas menunjukkan bahwa $p$ value sebesar 0,000 . Dari terlihat bahwa $0,000<0,05$ sehingga dapat disimpulkan bahwa Motivasi, Lingkungan Kerja dan Disiplin Kerja secara simultan berpengaruh terhadap Kinerja Guru. Dilihat dari

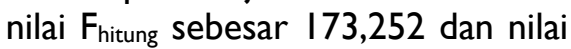
$F_{\text {tabel }}$ menggunakan nilai signifikansi $5 \%(\alpha=0,05)$ dan degree of freedom $\mathrm{dfl}(\mathrm{k}-\mathrm{I})$ dan $\mathrm{df2}(\mathrm{n}-\mathrm{k})$, yaitu $\mathrm{dfl}=$ $(4-I)=3$, dan $\mathrm{df} 2=(64-4)=60$ maka diperoleh nilai $F_{\text {tabel }}$ sebesar 2,76, sehingga dapat disimpulkan bahwa $F_{\text {hitung }}>F_{\text {tabel }}$ yaitu sebesar $173,252>2,76$. Dengan demikian hipotesis ke empat $\left(\mathrm{H}_{4}\right)$ diterima, yang berarti Motivasi, Lingkungan Kerja dan Disiplin Kerja secara simultan berpengaruh positif terhadap Kinerja Guru SD di Kabupaten Tangerang.

\section{Pembahasan}

Berdasarkan analisis yang telah diuraikan di atas dapat diketahui bahwa pada masingmasing variabel dan tingkatan besarnya kausal pengaruh antara variabel bebas terhadap variabel terikat. Dimana hasil tersebut menjadi pemaparan pembahasan sebagai berikut :

\section{a. Pengaruh Motivasi terhadap Kinerja Guru}

Berdasarkan uji statistik untuk variabel Motivasi $\left(X_{1}\right)$ menunjukkan bahwa thitung sebesar 2,848> $t_{\text {tabel }}$ yaitu 2,00030. Dapat disimpulkan bahwa Motivasi berpengaruh positif terhadap Kinerja Guru, ini berarti motivasi guru yang tinggi dapat meningkatkan kinerja, sebaliknya jika motivasinya rendah maka kinerja guru pun rendah.

\section{b. Pengaruh Lingkungan Kerja terhadap}

\section{Kinerja Guru}

Berdasarkan uji statistik untuk variabel Lingkungan Kerja $\left(\mathrm{X}_{2}\right)$ menunjukkan bahwa $t_{\text {titung }}$ sebesar 6,603> $t_{\text {tabel }}$ yaitu 2,00030. Dapat disimpulkan bahwa lingkungan kerja berpengaruh positif terhadap kinerja guru. Karena Lingkungan kerja dapat mendukung guru dalam melaksanakan tugas secara efektif dan efisien, dan dapat meningkatkan semangat kerja sehingga produktivitas kinerja pun meningkat.

\section{c. Pengaruh Disiplin Kerja terhadap Kinerja Guru}

Berdasarkan uji statistik untuk variabel Disiplin Kerja $\left(X_{3}\right)$ menunjukkan bahwa $t_{\text {thitung }}$ sebesar 4,669> tabel yaitu 2,00030. Dapat disimpulkan bahwa Disiplin Kerja 
berpengaruh positif terhadap Kinerja Guru. Karena disiplin yang tinggi dapat mencerminkan tingginya loyalitas, kesadaran atas peran dan tugas yang diemban, kesadaran atas peraturan dan ketentuan yang mengikat serta menjadi media motivasi untuk mendidik.

\section{d. Pengaruh Motivasi, Lingkungan Kerja dan Disiplin Kerja terhadap Kinerja Guru}

Berdasarkan uji statistik untuk variabel Motivasi, Lingkungan Kerja dan Disiplin Kerja terhadap Kinerja Guru menunjukkan bahwa $F$ hitung sebesar 173,252 > F tabel yaitu 2,76. Dapat disimpulkan bahwa Motivasi, Lingkungan Kerja dan Disiplin Kerja secara bersama-sama berpengaruh positif terhadap Kinerja Guru.

\section{V.PENUTUP}

\section{Kesimpulan}

Hasil uji statistik t (t-test) menunjukkan bahwa variabel Motivasi memiliki pengaruh positif signifikan terhadap Kinerja Guru. Artinya Motivasi guru yang tinggi dapat meningkatkan kinerja. Semakin tinggi keinginan dan kebutuhan seorang guru maka dorongan yang muncul akan semakin kuat.

Hasil uji statistik $\mathrm{t}$ (t-test) menunjukkan bahwa variabel Lingkungan Kerja memiliki pengaruh positif signifikan terhadap Kinerja Guru. Artinya lingkungan kerja yang baik dapat mendukung guru dalam melaksanakan tugasnya secara efektif dan efisien, dengan lingkungan kerja yang baik akan dapat meningkatkan semangat kerja para guru dan murid sehingga produktivitas kinerja pun meningkat.

Hasil uji statistik $\mathrm{t}$ (t-test) menunjukkan bahwa variabel Disiplin Kerja memiliki pengaruh positif signifikan terhadap Kinerja Guru. Artinya disiplin yang tinggi dapat mencerminkan tingginya loyalitas, kesadaran atas peran dan tugas yang diemban, kesadaran atas peraturan dan ketentuan yang mengikat serta menjadi media motivasi untuk mendidik sehingga dapat menghasilkan kinerja yang baik.

Hasil uji statistik F (F-test) menunjukkan bahwa variabel Motivasi, Lingkungan Kerja dan Disiplin Kerja secara simultan berpengaruh signifikan terhadap Kinerja Guru.

\section{Saran}

Perlu dilakukan monitoring dan evaluasi atas motivasi guru dan hal yang berkenaan dengan pelaksanaan tugas dan pekerjaan, serta pengendalian atas ketaat azasan profesi juga keteladanan yang bermuara dari pimpina sekolah.

Perlu dilakukan pengendalian yang tepat, terukur dan berkesinambungan agar tercipta dan terpelihara lingkungan kerja yang nyaman, fasilitas dan kelengkapan sarana \& prasarana penunjang kegiatan proses belajar mengajar.

Untuk mendorong dan menciptakan stimulus peningkatan kinerja guru, perlu diberlakukan punishment and reward yang ideal dan berimbang atau berjenjang dari manajemen sekolah bagi guru.

\section{DAFTAR PUSTAKA}

Abas, Erjati. 2017. Magnet Kepemimpinan Kepala Madrasah Terhadap Kinerja Guru, Jakarta : Penerbit PT. Elex Media Komputindo.

Arianto, Dwi Agung Nugroho. 2013 Pengaruh Kedisiplinan, Lingkunagn Kerja Dan Budaya Kerja Terhadap Kinerja Tenaga Pengajar. Universitas Islam Nahdatul Ulama Jepara. Jurnal Economia (Vol.9, No.2 Oktober 2013) Email : goeng_info@yahoo.co.id Baihaqi, Muhammad lqbal. 20I5. Pengaruh Gaya Kepemimpinan Kepala Sekolah Dan Motivasi Kerja Terhadap Kinerja Guru Di Ma Ma'arif Selorejo Blitar. Universitas Islam Blitar, Juli 2015, ISSN : 1979-9438 (Vol.7 No.2).

Ghozali, Imam, 2013. Metode Penelitian Kuantitatif, Bandung : Pustaka Setia.

Hamali, Yusuf Arif. 2018. Pemahaman Manajemen Sumber Daya Manusia, Jakarta : Penerbit PT. Buku Seru.

Hasibuan, Malayu S.P. 2012. Organisasi Dan Motivasi Dasar Peningkatan Produktifitas, Jakarta : Bumi Aksara.

Mangkunegara, Anwar Prabu. 20I5, Manajemen Sumber Daya Manusia Perusahaan Edisi 12. Bandung : PT. Remaja Rosdakarya.

Noor, Juliansyah. 2015. Metodologi Penelitian, Jakarta : Kencana.

Rina Oktiyani \& Kaman Nainggolan. 2016. Analisis Pengaruh Kompensasi Dan Lingkungan Kerja Terhadap Kinerja Guru di SMA Negeri I Klaten. Ecodemica, September 2016, ISSN : 2355-0295. (Vol.IV, No.2).

Sedarmayanti. 20II. Tata Kerja Dan Produktifitas Kerja, Bandung : Penerbit Cv. Mandar Maju

Siti Imroatun Dan Sukirman. 2016. Pengaruh Lingkungan Kerja, Kompensasi Kerja Dan 
Motivasi Kerja Terhadap Kinerja Guru Ekonomi/Akuntansi di SMA Negeri seKabupaten Wonosobo. Economic Education Analysis Journal, Semarang.

Sugiyono. 2013. Metode Penelitian Manajemen, Bandung : Alfabeta.

2016. Metode Penelitian Kuantitatif, Kualitatif, dan $R \& D$, Bandung :

http://ekonomi-

metronews.com/makro/wkBQAxeb-nasibguru-honorer-di-tengah-mandat-20anggaran-pendidikan. Diakses pada Sabtu 5 Mei 2018

http://tangerangonline.id/2016/I I/03/5-guru-dikabupaten-tangerang-masuk-daftar- penerimaan-sanksi/ Diakses pada Selasa 12 Juni 2018.

http://www.pikiran-

rakyat.com/opini2016/05/04kualitas-gurukita-368286 Diakses pada Sabtu 5 Mei 2018.

http://www.skhn0l kabtentangerang.sch.id/html/i ndex.php?id=profil\&kode=5 I \&profil=Adiwi yata Diakses pada Kamis 10 Mei 2018.

sekolah.data.kemdikbud.go.id/index.php/chome/ pencarian Diakses pada

Senin I4 Agustus 2018. 